\title{
Estudios actuales de las culturas aborígenes canarias
}

\author{
M. ${ }^{a}$ Isabel Martinez Perello
}

El estudio de la Prehistoria canaria se remonta al menos hasta el siglo $x \mathrm{~V}$, pero su análisis científico es más moderno. Sin embargo, éste se realizó basándose en un sistema comparativo de origen evolucionista, incluyendo a las Islas Canarias en los fenómenos mediterráneos generales y sin relacionarlas como el mundo africano, con el que tienen significativos paralelos.

Hacia la década de los setenta, un nuevo impulso revitaliza los estudios sobre la Prehistoria del archipiélago, creándose además el Departamento de Arqueologia y Prehistoria de la Universidad de La Laguna. Sin embargo, los problemas a resolver siguen siendo, como en un principio, el origen de la población oborigen y la cronologia del poblamiento.

Desde hace unos años, ya en la década de los setenta, los profesores Antonio Tejera Gaspar, catedrático de la Universidad de La Laguna, y Rafael González Antón, actual Director del Museo Arqueológico y Etnográfico de Tenerife, han intentado aproximarse a la Prehistoria de las islas basándose tanto en los aspectos materiales conocidos como en las fuentes escritas, realizando además análisis etnohistóricos en los que se buscan parentescos socioculturales entre los aborígenes canarios y los pueblos paleoberéberes o beréberes, entre los que las influencias atlántico mediterráneas inciden sobre un substrato autóctono. Con todo ello han abierto nuevas vias de estudio, ampliando el estrecho marco que ofrece la arqueología canaria. Fruto de estas investigaciones y planteamientos es la obra de dichos investigadores, Antonio TEJERA GASPAR y Rafael GonzAlez ANTON, Los aborigenes canarios. Gran Canaria y Tenerife (La Laguna, 1981), agotada hace años y reeditada con una pre- 
sentación del profesor J. M. Gómez-Tabanera (Oviedo, Ediciones Istmo, 1990, 372 págs. con figs.).

Tras dicha presentación, en este libro se expone, en primer lugar, la metodología de estudios seguida, con la utilización de diversas disciplinas como la etnohistoria, la lingüística y la antropología física, a fin de aproximarse a la resolución de problemas como el poblamiento de las Islas Canarias y su cronologia absoluta (C14). Tras esta introducción, los autores tratan en diez densos capítulos todos los temas que atañen a las expresiones culturales de la población aborigen tinerfeña y grancanaria, expresiones que estos pueblos supieron mantener en estado primitivo hasta su conquista en el siglo xv por el bretón Jean de Bethencourt y su incorporación a la Corona de Castilla. Se trata, pues, todo lo concerniente a la población aborigen prehispánica, su organización social y estructura política, su economía, religión, prácticas de enterramiento, vivienda, expresiones artisticas materializadas en grabados y pinturas rupestres y su cultura material. Finaliza la obra con un Apédice (págs. 321-357), incorporado en la presente edición, en el que se puntualizan determinados aspectos o planteamientos que al cabo de diez años ha sido necesario revisar. Así recogen, por ejemplo, la valoración crítica a su planteamiento ecléctico realizada por F. ESTÉVEZ GONZALEZ (1987) en “Indigenismo, Raza y Evolución». Otro tema que retoman es el de la defensa del poblamiento tardio de las islas en una fecha no anterior a la primer mitad del I milenio a. C., lo que no es aceptado plenamente por otros investigadores de la Prehistoria canaria. Incorporan también una breve nota de Bertilia GaLVÁN SANTOS sobre la industria tallada de Tenerife y Gran Canaria y otro apéndice en el que se reimprime la comunicación presentada por los autores al "XVIII Congreso Nacional de Arqueología (Las PalmasTenefife, 1985)" sobre las relaciones culturales entre el Medirerráneo y el archipiélago entre el IV y el II milenios a. C.

Este magnífico trabajo supuso, ya en el momento de su primera publicación, un revulsivo para el estudio de la arqueologia canaria, pues subrayó la necesidad y la urgencia de un replanteamiento teórico y una nueva reconstrucción histórica, por lo que es de agradecer que haya sido reeditado y actualizado.

Esta misma línea se presentaba en la obra de los mismos autores, Las culturas aborigenes canarias (Santa Cruz de Tenerife, Interinsular Ediciones Canarias, 1987, 202 págs.), prologada por el profesor Rodrigo de Balvin BEHRMANn, quien la considera cinteresante, bien planteada, valiente e independiente de planteamientos políticos, capaz y abridora de nuevos caminos (...) procura y consigue observaciones históricas". 
Los autores, tras repasar la historia de la historiografía - deteniéndose en la influencia del difusionismo alemán, la interpretación racista de Schwidetzky, y el estudio de los materiales arqueológicos, que no consideran adecuado hasta que empezaron a estudiarlos el profesor $C$. Martín de Guzmán, el Departamento de Prehistoria y Arqueologia de la Universidad de La Laguna y el Museo Canario-, proponen, como en la obra anterior, la colaboración del trabajo arqueológico científico y otras disciplinas auxiliares (etnohistoria, análisis cross-cultural, etc.) y de nuevo defienden el origen africano y relativamente reciente del poblamiento del archipiélago.

En los siete capitulos siguientes analizan cada una de las culturas isleñas prehispánicas: su habitat, economia, organización social y politica, mundo religioso, funerario y ritual, tratando de acercarnos a la diversidad $y$, a la vez, a la homogeneidad que éstas presentan. Concluyen con un capítulo dedicado a la dramática desaparición del mundo aborigen, la eliminación física de la mayoría de la población, la transformación irreversible del paisaje y el territorio, los cambios socio-económicos y religiosos... y todo lo que provocó la auténtica absorción de los grupos primitivos por la sociedad conquistadora.

Los autores buscan en este estudio un marco referencial válido, próximo y real para poder entender las estrategias adaptativas que siguieron las distintas etnias cuando poblaron las islas hasta llegar a conformar la diversidad cultural isleña, rechazando la idea derivada del difusionismo alemán de una unidad cultural - "cultura de substrato" (L. D. Cuscoy) o "cultura pancanaria" ( $M$. Tarradell)- - y realmente consiguen una obra sumamente interesante y valiente, en la que se aportan nuevas claves para el conocimiento de la Prehistoria canaria.

Claves que también se ofrecen en la obra de A. TEJERA GASPAR, La religión de los guanches (ritos, mitos y leyendas) (Santa Cruz de Tenerife, Caja Canarias, 1988, 126 págs., 9 figs. y 15 láms. en color). En ella, pese a las dificultades que ofrece el tema por su principal fundamentación en las fuentes escritas - relatos de viajeros anteriores a la conquista de Tenerife, Bulas papales y documentación eclesiástica- y en la arqueología, el autor nos sumerge en el mundo mágico-religioso guanche, realizando un estudio global de su mundo cognitivo y comparándolo, mediante un análisis cross-cultura, con fenómenos similares de la cosmovisión del resto del archipiélago al proceder todo él del mismo ambiente cultural de origen beréber. Para ello parte del concepto de religión como una manifestación eminentemente social, siendo las representaciones religiosas hechos colectivos que expresan realidades de una sociedad, lo que le permite estudiar los diferentes mecanismos culturales y sociales y 
aproximarse a la religión guanche: los seres supremos, los espiritus y antepasados, ritual y tabú, economía y ritual, y mitos y leyendas.

Queremos finalizar este recorrido por la actualidad de los estudios canarios con una breve referencia a la obra de A. TEJERA GASPAR y E. AZNAR VALLEJO, El asentamiento franconormando de "San Marcial de! Rubicón" (Yaiza, Lanzarote) (Un modelo de arqueología de contacto), (Santa Cruz de Tenerife, Ayuntamiento de Yaiza, 1990, 242 págs. con amplia ilustración). Se presenta como parte de un proyecto de investigación arqueohistórico que pretende aproximarse al conocimiento de los siglos XIV y XV en Canarias, y que se inicia con este trabajo, memoria de la primera intervención arqueológica realizada en el yacimiento que constituyó la primitiva ciudad de "San Marcial del Rubicón", cuyo castillo fue excavado por los hermanos Serra Ráfols en la década de los sesenta. Contiene estudios complementarios de Mercedes Martín Oval, Arturo Hardisson de la Torre, José Manuel Hernández Moreno y Jaime Delgado Baudet.

Los autores se han apoyado tanto en la documentación escrita existente como en la arqueológica, que de momento se ha limitado a prospección de todo el conjunto. Esperamos que la investigación continúe y permita desvelar aspectos claves sobre el contacto sobre los aborígenes de Lanzarote, los majos y los primeros europeos que allí llegaron, asi como sobre el proceso de transculturación posterior sufrido por estas poblaciones prehistóricas. 